\title{
An Assessment of SME Competitiveness in Indonesia
}

\author{
- Setyawan Agus Anton, Isa Murakan, Wajdi Farid Muhammad, Syam- \\ sudin, Nugroho Permono Sidiq
}

\begin{abstract}
The purposes of this study are to analyze source of SME competitiveness in selected industry clusters in Indonesia and to develop a theoretical model of SME competitiveness. This study employs quantitative design with multivariate model. We develop three models of estimation by using multiple regression analysis. Our models are based on Porter Model of Competitiveness (1990) which contains factor condition, demand condition, related and supporting industries and business strategy. Findings in this study idenntify sources of the competitiveness of SME in the level of innovation, entrepreneurship, human capital, financial resources, potential market and business strategy. Limitation of this study lies in the SME model of competitiveness based on cross sectional data which is not feasible for analysis of the dynamic aspect of competitiveness sources. Our findings show that SMEs need government assistance to develop marketing networks and access to financial institutions.
\end{abstract}

Keywords: Competitiveness, level of innovation, entrepreneurship, business strategy.

JEL Classification: L 16

\section{INTRODUCTION}

Research on SME has been developed since the growth of debat upon role of this business organizations to economic development (Gunasekaran et al.,2011; Capo-Vicedo et al., 2008). One of the debates that has been emerge among business scholar is how to increased SME competitiveness (Rostek, 2012; Ada et al., 2013). Rostek (2012) argues that SME needs to improve competitiveness to survive in a changing environment and strong business competition. Ada et al., (2013) found competitiveness of SME could increase their bargaining position in business competition.

Porter (1985) wrote concept of value chain that become basic foundation of competitiveness. Value chain is a set of activities that are useful to design, produce, market, deliver and support its product (Ankli, 1992). This concept has been developed into many firms and organizations including SME.

There is certain research question addressed in this study; what are factors affecting SME competitiveness? Business networks and relationship with business partners are source of SME competitiveness (Gracia et al., 2011; Karaev et al.,2007; Bek et al., 2013). Business networks for SME related with the fact that this business has limited resources. Morgan and Hunt (1994) explain that business and competition has shift from company competition to business network com- 
petition. SME cluster is a form of business network which developed in many countries, such as Spain (Gunasekaran et al.,2011; Gracia et al., 2011), Russia (Bek et al., 2013), Turkey (Ada et al., 2013), Italy (Randelli and Lombardi, 2013) and Indonesia (Tambunan, 2009). Tambunan (2009) adresses to achieve optimum resource sharing in Indonesia SME, they should develop themself into SME clusters.

Tambunan (2009) identifies several key issues for improving SME competitiveness in Indonesia, they are human resource, working capital, management and technological skills. These key factors are important to improve SME's business performance. Lamprinopoulou and Tregear (2011) find that SME business network has major contributions to their marketing performance.

Bek et al., (2013) notify that innovation in SME cluster is crucial to improve their business performance. Innovation leads to ability to create product and business process with property rights and intangible assets. Capo-Vicedo et al.,(2008) explain those are keys in improving business performance in SME cluster. Tambunan (2009) and Sener et al., (2014) find that financial access is very important to SME's business performance.

This study analyzes SME competitiveness in three different clusters in Indonesia. There are three SME manufacturing clusters that become main focus in this study. They are mushroom cluster in Jogjakarta, rattan furniture cluster in Trangsan, Sukoharjo and shoes and sandals cluster in Mojokerto.

\section{LITERATURE REVIEWS AND RESEARCH HYPOTHESES}

\subsection{SME In Indonesia: Problems and Realities}

Small and Medium Enterprises (SME) in Indonesia gives significant roles to this country's economic development. Tambunan (2009) identifies five characteristics of SME in Indonesia which makes this business important for this country's economic development. First, SME in Indonesia mainly owned by local people and it absorbs millions of workforce in the country. Second, SME is very common in rural areas, and their business based on agriculture, thus they are become important for rural economic development. Third, SME is labor intensive, with many less-educated and youngsters involved in the business. Fourth, SME in Indonesia obtain their financial operations from personal savings. Fifth, this businesses produce simple consumer goods. They serve domestic market and targeted on low income consumers. Tambunan (2009) also clarifies that SME in Indonesia includes micro business.

Tambunan (2008) explains common problems of MSME (Micro, Small and Medium Enterprises) in Indonesia are as follows:

1. Lack of working capital;

2. Marketing difficulties;

3. Limited access to financial resources;

4. Lack of technological skills and management;

5. Low productivity; 
6. Limited access to productive resources, particularly capital, technology, information and markets;

7. The still low quality of institutions and organization of cooperatives;

8. Lack of business networks.

Small to medium enterprise (SME) in Indonesia has learned from 1998 economic crisis. In fact, the revival of Indonesia's SME is a result of the 1998 financial crisis. During 1998 financial crisis, SME become the last social safety network. In 1998, the unemployment rate in Indonesia was increasing rapidly. There's almost 12 million people considered open unemployment or else 11 percent of labor force in Indonesia are unemployment.

Tab. 1 - Selected Indicator of SME Development in Indonesia 2013, Source: Departemen Koperasi dan UMKM Indonesia, 2014

\begin{tabular}{|c|c|c|c|c|}
\hline Business Category & $\begin{array}{c}\text { Number of } \\
\text { Companies }\end{array}$ & Employee & $\begin{array}{c}\text { PDB } \\
\text { Contributions } \\
(\%)\end{array}$ & $\begin{array}{c}\text { Investments } \\
\text { (Billion Rp) }\end{array}$ \\
\hline Micro Enterprise & $55,856,176$ & $99,859,517$ & 35.81 & $175,529.1$ \\
Small Enterprise & 629,418 & $4,535,970$ & 9.68 & 452.790 \\
Medium Enterprise & 48,997 & $3,262,023$ & 13,59 & 622.482 \\
Big business & 4,968 & $3,150,645$ & 40,92 & $1,033,071.9$ \\
\hline
\end{tabular}

Table 1 shows the contradiction of SME performance in Indonesia. Indonesia SME gives high contribution in labour absorption in Indonesia. There is almost 75 percent of employment in Indonesia works in SME. It also gives enormous contribution to the country's PDB. SME also dominates the amount of companies in Indonesia. However, it only gives minor contribution to the country's product domestic bruto as well as investment rate.

Indonesia's SME has several problems to maintain their sustainability. Table 1 shows weakness of this business and it should give alert to SME. Karaev et al., (2007) acknowledge SME facing two challenges in the current global business competition. First, SME have to respond to business opportunities that widely open as a result of globalizations. Second, SME should create and maintain business networks in order to develop their business.

\subsection{Porter Model of Competitiveness}

Over the last decade, trade globalization and liberalization have significantly increased customer expectations and competition among companies. In the current global competition age, SMEs facing two challenges: (1) how to increase individual competitiveness and (2) how take advantage of synergy created in SME network (Karaev et al., 2007). Furthermore, SMEs have played a very important role in developing economies. They were able to get the opportunity to enter the market better than larger firms due to systemic change. 
Competitiveness remains a concept that is not well understood, despite widespread acceptance of its importance. Porter (1985, p 102) defined competitiveness as implementation of value creating strategy by a company and not simultaneusly implemented by competitor and these strategy is not easily duplicated. Man et al. (1998) argue that the process of SMEs to achieving the competitiveness is strongly influenced by the key player. Key player is leading firm in SME clusters (Randelli \& Lamberdi, 2014). In SME cluster, there are several firms that become leader due to their business size, human resource and technological skills, profitability, financial access and capability and market access (Setyawan et al.,2012).

The appropriate unit analysis in setting competitive strategy is industry. Strategically, an industry may be distinguished from another by fact it proposes products that have similar sources of competitive advantage (Passermard \& Kleiner, 2000). On every competitive strategy, there are two components to be distinguished, they are: the structure of the industry. Second, the positioning of the enterprise with the industry that some positions will be more advantageous than another in various profitability level.

Porter (1998) developed model of competitiveness with four determinants: factor conditions, demand conditions, related and supporting industry, and business strategy, structure and competition. Porter (1990) and Bennet \& Smith (2002) conclude several factors in competitiveness resource of an industry. Those include:

1. Factor conditions, which includes availability of skills, infrastructure, capital, innovation and entrepreneurism.

2. Demand conditions, which include product development, industry structure, local purchaser and distribution system, market size and agglomeration.

3. Related and supporting industry is a representation of suppliers and customers existence in the industry.

4. Business strategy, structure and competition show how firm compete in the industry by using their business strategy.

Bennet \& Smith (2002) offer a model of industry competitiveness based on Porter Model of Competition and we develop the estimation model in multivariate statistics model. Tambunan (2009) proposes source of competitiveness and also weaknesses of SME in Indonesia are lack of working capital, marketing difficulties, limited access to financial resources, lack of technological skills and management, low productivity, limited access to productive resources, particularly capital, technology, information and markets, low quality of institutions and organization of cooperatives and lack of business networks. These two concepts are fundamental basic for our model of SME competiveness.

We propose the result of those competitive factors is business performance. Furthermore, we conclude business performance in the multivariate model as dependent variables which affected by competitive factors. Cocca \& Alberti (2010) reveal business performance in SME usually measured with their financial capability. In this study we combine our measurement of SME performance by add marketing performance to complement financial performance. 


\subsection{Business Performance for SME}

Business performance for SME has similar issue with any other organizations; to determine appropriate measurement. Pavlov and Bourne (2011) propose performance measurement gives certain effect to organization performance, and it moderated with the trigger and guidance of the performance measurement.

Tambunan (2009) explains SME business performance in Indonesia ussualy measured by selling revenue, market growth and financial capacities . Lamprinopoulou and Tregear (2011) found that SME should also have detail and clear performance measurement with longterm orientation, such as marketing performance. However, SME have problems in the definition of business performance since most of SME still struggling with surviving the business (Tambunan, 2009).

\subsection{Human Resource Aspect and Level of Education}

Level of education of SME owner is our proxy of lack of technological skills and management in the business. Tambunan (2009) reveal one of important characteristics in Indonesia's SME is the owner is also the manager and employee, thus, to develop SME human resource skill means into develop the owner's technological and management skills. Devins et al., (2004) emphasize the importance of competence human resource in SME. In order to increase human resource competence, training development in SME should be enhanced (Devins, et al., 2004). However, SME rarely develop training program for their employment as well as the owner (Richbell et al., 2010; Jones, 2001). SME usually do not aware of their human resources problem (Ricbell et al., 2010). Kato et al., (2015) verify that level of education of human resources is more likely to yield innovation outcomes.

\section{H1 Level of education has positive effect on SME business performance}

\subsection{Capital and Financial Resources}

Financial capacities for SME are one of important constraints. Tambunan (2009) explains SME in Indonesia suffers poor access to financial institution, such as bank or other financial institution. Klonowski (2012) found similar condition in Poland. SME in Poland suffers serious liquidity gaps, thus it prevent their business development. This condition occurs due to SME inability to arrange business planning and risk assessment documents (Tambunan, 2009). Hussain et al., (2006) discovered SME in developing countries relies their financial support from their immediate family. This circumstance continues for two or three years and after their business is developed then they have approached by bank and other commercial institutions to earn certain loans (Hussain et al., 2006). Neupert et al., (2006) notify SME needs various financial support when their business expanded to export orientation.

H2 Working capital has positive effect on SME business performance 


\subsection{SME's Level of Innovation}

Innovation for SME related with their effort to quest new business opportunities, product, market and organization development (Ahlstrom-Soderling, 2003). Rostek (2012) proposed a model of innovation to support competitiveness in SME. This study concludes that innovation in SME related with strategic decision making in the organization. Antonioli and Pinni (2011) proposes innovation in the business organization occurs when company enhance their human resource quality and business networks. Kato et al., (2015) found that human capital innovation, such as prior innovation experience related with innovation outcomes of SME. Egbu et al., (2005) describe that process of encouraging innovation in SME is not simple. It involves an evolution of people, culture, finance, technology and organizational structures as a core (Egbu et al., 2005). Antoniolli and Pinni (2011) propose level of innovation in business includes: expand a new strategy of promotion, creating new supplier, distribution network and buyer, enhancing new product to the market.

\section{H3 Level of innovation has positive effect on SME business performance}

\subsection{Developing Business Strategy for SME}

Business strategy is a key component for company. Business strategy includes business plan and tactics a company should developed in a certain business condition (Neupert, et al., 2006). SME should execute their business strategy since it is a nature way in business and we believe that they have developed it, however it is rarely, SME compile business strategy documents (Gilmore et al., 2001). Bennet and Smith (2002) determine business strategy as a process of assessment on business performance, setting business target and business plan periodically. Şener et al., (2015) confirm that SME needs to shape their business strategy by choosing business with high economic value added. This step of formulating strategy will give contribution to SME competitiveness (Ada et al., 2013). Ankli (1992) notice that value chain analysis gives details step of strategy formulation.

H4 Business strategy has positive effect on SME business performance

\subsection{SME Competitiveness Conceptual Framework}

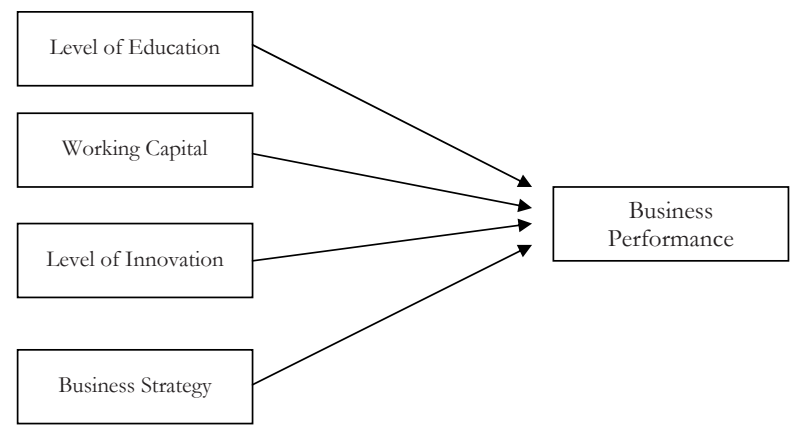

Fig. 1 - SME Competitiveness Conceptual Framework. Source: Karaev et al., (2007), Randelli and Lombardi (2013) 


\section{RESEARCH METHODS}

\subsection{Design of the Study}

The design of this research is quantitative with survey in three different kinds of SME clusters. Tambunan (2009) reveals that SME clusters in Indonesia have become main strategy for Indonesia administration to build SME business networks. We choose SME clusters of mushroom in Jogjakarta, rattan furniture in Trangsan, Sukoharjo and shoes and sandals in Mojokerto. The selection criteria of these three clusters are based on Bank Indonesia evaluation that these three clusters have strong economic impact to local economic development.

\subsection{Data and Sample Size}

Population of this study is SME in three different clusters. They are rattan furniture SME in Trangsan Sukoharjo, Central Java, mushroom SME in Yogyakarta and shoes and sandals SME in Mojokerto, East Java. There are more than 300 SME in Trangsan, 40 SME mushroom SME in Yogyakarta and more than 250 shoes and sandals SME in Mojokerto.

We apply purposive sampling method in sampling methods. Selected characteristics of our respondents are they should be more than 3 years in business, appropriate profit and those SME has business network. In this survey, we found 89 SME as respondents from Trangsan, 93 SME from Mojokerto and 24 mushrooms SME from Yogyakarta. In total we obtain 206 respondents as observations of this study. There are different categories of SME respondents in this study; they are small and micro companies. Our categorization of SME follows 20th Indonesian SME Act 2008. Based on this regulation, there are three different categories of SME:

a) Micro Business is SME with total assets below IDR 50 millions and annual selling IDR 300 millions.

b) Small Business is SME with total assets from IDR 50 millions to IDR 500 millions and annual selling from IDR 300 millions to IDR 2.5 billions.

c) Mid-Sized Business is SME with total assets from IDR 500 millions to IDR 10 billions and annual selling from IDR 2.5 billions to IDR 10 billions.

\subsection{Model Estimation}

We develop multivariate statistic model to estimate the effects of level of education, working capital, level of innovation and business strategy to business performance.

Equation 1 is multivariate statistic model of this study:

Business Performance $=a+b_{1}$ level of education $+b_{2}$ working capital $+b_{3}$ level of innovation $+\mathrm{b}_{4}$ business strategy $+\mathrm{e}_{1}$ 


\subsection{Measurement}

Tab. 2 - Measurement of Variables, Source: Jones (2001), Klonowski (2012), Antonioli et al, (2011), Bennet \& Smith (2002), Cocca \& Alberti (2010)

\begin{tabular}{|c|c|c|c|}
\hline No & Constructs & Dimension and Measurement & Source \\
\hline 1. & $\begin{array}{l}\text { Level of Edu- } \\
\text { cation of SME } \\
\text { owner. }\end{array}$ & SME owner years of school. & Jones, (2001). \\
\hline 2. & $\begin{array}{l}\text { Working } \\
\text { capital }\end{array}$ & $\begin{array}{l}\text { Amount of cash in a period of production } \\
\text { in IDR. }\end{array}$ & Klonowski (2012). \\
\hline 3. & $\begin{array}{l}\text { Level of In- } \\
\text { novation }\end{array}$ & $\begin{array}{l}\text { Develop a new strategy of promotion, } \\
\text { creating new supplier, distribution network } \\
\text { and buyer, enhancing new product to the } \\
\text { market. All dimension measured with rat- } \\
\text { ing scale from never to always. }\end{array}$ & Antonioli et al., (2011) \\
\hline 4. & $\begin{array}{l}\text { Business } \\
\text { Strategy }\end{array}$ & $\begin{array}{l}\text { SME periodically has an assessment on } \\
\text { their business performance, setting busi- } \\
\text { ness target and business plan measured } \\
\text { with rating scale. }\end{array}$ & Bennet \& Smith (2002) \\
\hline 5. & $\begin{array}{l}\text { Business Per- } \\
\text { formance }\end{array}$ & $\begin{array}{l}\text { Percentage growth of SME profitability } \\
\text { in the last three years }\end{array}$ & $\begin{array}{c}\text { Cocca \& Alberti, } \\
\text { (2010). }\end{array}$ \\
\hline
\end{tabular}

Table 2 shows measurement and variables in this research. This research employs different types of scales. Level of education, working capital and business performance measured with ratio scale, while business strategy and level of innovation with likert scale.

\section{DATA ANALYSIS}

\subsection{Validity and Reliability}

In this research, we employ confirmatory factor analysis (CFA) to analyse validity of the measurement. We also conduct assessment of measurement reliability by using Cronbach Alpha. Table 3 shows result of validity and reliability analysis. 
Tab. 3 - Validity and Reliability Results, Source: Raw Data Analysis

\begin{tabular}{|c|l|c|c|}
\hline \multirow{2}{*}{ Construct } & \multicolumn{1}{|c|}{ Item } & $\begin{array}{c}\text { Factor } \\
\text { Loadings }\end{array}$ & $\begin{array}{c}\text { Cronbach } \\
\text { Alpha }\end{array}$ \\
\hline \multirow{3}{*}{$\begin{array}{c}\text { Level Of Innova- } \\
\text { tion }\end{array}$} & 1. Creating new promotional mix & 0.652 & \\
& 2. Exploring for new buyer & 0.885 & \\
& 3. Exploring for new supplier & 0.835 & \multirow{2}{*}{0.8525} \\
\hline \multirow{2}{*}{$\begin{array}{c}\text { 3. Developing new products } \\
\text { Development }\end{array}$} & 2. Performance assessment & 0.872 & \\
& 3. Det up business target & 0.686 & \\
\hline
\end{tabular}

Table 3 shows that all item in level of innovation and business strategy development constructs has factor loadings above 0.5 which consider valid (Hair et al., 2010) . Business strategy development and level of innovation constructs has also strong internal consistency with Cronbach Alpha correlation above 0.6.

We analyze descriptive statistic for three other variables, they are level of education, business performance and working capital. The scale measurement of those three variables are ratio, therefore it has to follow normal distribution. Table 4 shows result of descriptive statistic of level education, business performance and working capital.

\subsection{Statistics Descriptive and Normality Test}

Tab. 4 - Results of Statistic Descriptives. Source: Raw Data Analysis

\begin{tabular}{|c|c|c|c|}
\hline & Level of Education & Business Performance & Working Capital \\
\hline Mean & 9.30 & 243762997.57 & $219,363,325$ \\
Median & 9.00 & 25350000 & $20,000,000$ \\
Mode & 6 & 0 & $20,000,000$ \\
Skewness & 0.146 & 13.915 & 12.489 \\
Std Error of Skewness & 0.169 & 0.169 & 0.169 \\
Kurtosis & -0.364 & 197.329 & 163.718 \\
Std Error of Kurtosis & 0.337 & 0.337 & 0.337 \\
\hline
\end{tabular}

Table 4 shows result of statistic desriptive of level of education, business performance and working capital. We analyze normality test by divide skewness and kurtosis of each variables with standard error of skewness and standard error of kurtosis. The result shows that those three variables does not follow normal distribution. We decide to execute transformation for level of education, business performance and working capital in to logarithm. 


\subsection{Model Estimation and Hypothesis Testing}

Tab. 5 - Assessment of SME Competitiveness Estimation Result. Source: Raw data Analysis

\begin{tabular}{|c|c|}
\hline Antecedents & Standardized Coefficient \\
\hline Log Level of education & $0.602^{* *}$ \\
Log Working capital & $0.125^{* *}$ \\
Level of innovation & $0.213^{* *}$ \\
Business Strategy & 0.099 \\
\hline
\end{tabular}

F stat $68.696^{* *}$

$\mathrm{R}^{2}=0.580$

** Significant at $5 \%$ level.

Dependent variable: Log Business Performance

Our estimation of the model shows that each independent variables significantly has positive effect to business performance. We also has moderate goodness of fit in the model with coefficient of determination or R square 0.580 .

\section{DISCUSSIONS}

Level of education shows that in those three industrial clusters higher education level of the owner means higher business performance. It shows that educated entrepreneur have better competitiveness than non educated one. Lipsey and Sjoholm (2006) estimate impact of level of education to payment level in manufacture industries in Indonesia. White collar workers receive better payment than blue collar one. Findings of this study show similar result with Lipsey and Sjoholm (2006). Level of education in SME industry related with ability to conduct business plan and risk determination in the business. This finding gives a lesson to SME industry that human resource plays important role in building competitiveness.

Working capital has a positive significant effect to business performance in selected SME industry. Financial capabilities of SME in those three clusters rely on non-bank resources, such as financial support from immediate family. However, several respondents which have a stable business in the past five years tend to switch their financial support to bank or other legal financial institution. This phenomenon is similar to UK and China SME financial support behavior (Hussain et al., 2006). In those two countries, SME gain their financial support from their family as a start up, and then after two years, they start to have a business relationship with bank as their financial support (Hussain et al., 2006).

Level of innovation plays a key role in SME business performance. This could be the most important finding in this study. It explains that SME with high level of innovation could benefit high company growth. Antonioli and Pinni (2011) explain the situation with his framework of level of innovation. In the framework, economic value added of each product is a source of innovation. 
Business strategy development of SME will encourage business performance. SME should construct their business plan, setting up the target and evaluate their business achievement periodically. Pavlov and Bourne (2011) propose this situation as building trigger and guidance for organizations to compile appropriate business target and performance measurement.

Business performance of SME in this study explained by level of education, working capital, level of innovation and business strategy. Model of estimation in this study has moderate goodness of fit, but it fulfill all BLUE assumptions. It shows that this model is an appropriate method to assess SME competitiveness in Indonesia.

\section{CONCLUSSIONS AND IMPLICATIONS OF THE STUDY}

\subsection{Human Capital in SME Development}

Our models of SME competitiveness shows level of education have positive effect on company growth. This finding related with the role of human capital in SME development. Finding of this study about human capital is similar with Richbell et al., (2010) who found that lack of skill in SME do not affect their productivity. This occurs due to ability of SME owner to learn fast about newest market trend. In this study, most of SME hired their family members and sometimes they treated professionally. Human capital in this study is related with innovation in SME business. Human resources with high skills and competences are required in those three different businesses in this study.

Average level of education of SME owner is high school level, although many of them have college education background. Usually, SME with college education background is second generation of owner. They have better understanding about their business, accept modern view of business and aware of their business sustainability. This group of SME concentrated on export oriented industry that is rattan furniture. However, in mushroom SME industry qualified human resource could be identifies from their attempt to develop mushroom product and business network. Our observations in shoes and sandals SME in Mojokerto, show the importance of human capital. In this business, SMEs are partners of mutinational companies with limited authority to develop product and business process innovation. It explains why SMEs in shoes and sandals have high dependency to their business partners.

\subsection{Financial Aspect and Capital Definition}

Our findings in this study include the important role of working capital in SME development. SME in the selected clusters have similar assumption that capital is only working capital. They are convinced that capital is amount of money they need to make a product in certain period. They are disregarding several cost structure such as fixed assets (i.e., plant and production tool) and also labour cost. Most of SME in those three clusters complete production process in their residence. Thus, SME plant is owner residence. This is the reason they do not include plant as part of business assets. Most of SME in this study have their family members as employees. Regularly, important part of management holds by close family members, such as spouse or children. Eventually, it makes it difficult to compile proper minimum wage. 
Those two facts are reason why SME in this study only count working capital as amount of money required of manufacturing in certain period. 80 percent of SME in this study make use of their own financial resource as working capital. There are only 20 percent SME in selected clusters are bankable. Most of this group available only for consumptive loan such as bank loan to buy vehicle. Banks could not reach most of SME in those three clusters, since they are lack of ability to compose their business financial plan. Unability of compiling financial plan of SME also has effect on their awareness of business risks. Our observation shows these three SME clusters less pay attention to business risks.

\subsection{Level of Innovation and Business Strategy}

We find that SME should strengthen their level of innovation and business strategy to increase their business performance. SME owner in those three clusters always create product innovation, such as develop a new design or finding more economic raw materials. SME in rattan furniture and mushroom clusters maintain their innovation for different reason. SME in rattan furniture introduce product innovation since they have to face global competition with China and changes in global demand.

SME in mushroom rattan develop their innovation since mushroom product is in the early stage of product and market development. Rattan furniture SME has conduct innovation by product development and market extension. They develop their product by creating new product from substitute raw material such as, water hyacinth, banana stem and sea screw pine. Mushroom SME develop their product by creating efficient way of growing mushroom seeds. They have succeed in developing second stage of seed (usually known as F2), while first stage (F1) is their challenge. However, we find SME in shoes and sandals totally relied on national shoes industries in developing their product. Market development in this SME is also very limited.

We find that business strategy has positive effect on business performance. However, 85 percent of SME in the selected clusters do not execute business strategy planning. If they do, their business strategy planning is limited on marketing plan, even though comprehensive business plan is more important. Ahlstrom-Soderling (2003) found that SME business plan should include business networks plan. Our result confirms this finding. We find that there is certain business network in every SME cluster.

There are several limitations in this study. First, there is still unclear definition of capital measurement in SME. We failed to convince our respondents to answer complete capital which includes fixed assets and tools of production. Second, human capital in this study related with level of education. However, there are a lot aspects of human capital, such as training and business experiences. We do not include those two aspects in human capital discussions, since we do not have data level to support our discussions. Third, business performance in SME is one of the important debate in its measurement. We use SME profitability growth as a business performance assessment. However, there are many business aspects performance such as business growth, market share, total revenue and customer satisfaction and loyalty. A complete assessment of business performance will enrich information of SME competitiveness. 


\section{References}

1. Ada, E., Kazancoglu, Y., \& Sagnak, M. (2013). Improving Competitiveness of Small and Medium-Sized Enterprises (SMEs) in Agriproduct Export Business Through ANP: The Turkey Case. Agribusiness, 29(4), 524-537, http://dx.doi.org/10.1002/agr.21320

2. Ahlstrom-Soderling, R. (2003). SME Strategic Business Networks Seen as Learning Organizations. Journal of Small Business and Enterprise Development, 10(4), 444-454. http:// dx.doi.org/10.1108/14626000310504756

3. Ankli, R. E. (1992). Michael Porter's Competitive Advantage and Business History. Business and economic history, 228-236.

4. Antonioli, D., Mazzanti, M., \& Pini, P. (2011). Innovation, industrial relations and employee outcomes: evidence from Italy. Journal of Economic Studies, 38(1), 66-90. doi:10.1108/0144358 1111096150

5. Bek, M. A., Bek, N. N., Sheresheva, M. Y., \& Johnston, W. J. (2013). Perspectives of SME innovation clusters development in Russia. Journal of Business \& Industrial Marketing, 28(3), 240-259. doi:10.1108/08858621311302895

6. Bennett, R. J., \& Smith, C. (2002). Competitive conditions, competitive advantage and the location of SMEs. Journal of Small Business and Enterprise Development, 9(1), 73-86. doi:10.1108/ 14626000210419509

7. Capó-Vicedo, J., Expósito-Langa, M., \& Molina-Morales, F. X. (2007). Improving SME competitiveness reinforcing interorganisational networks in industrial clusters. International Entrepreneurship and Management Journal, 4(2), 147-169. doi:10.1007/s11365-007-0059-7

8. Cocca, P., \& Alberti, M. (2010). A framework to assess performance measurement systems in SMEs. International Journal of Productivity and Performance Management, 59(2), 186-200. doi:10.1108/17410401011014258

9. Devins, D., Johnson, S., \& Sutherland, J. (2004). Employer characteristics and employee training outcomes in UK SMEs: a multivariate analysis. Journal of Small Business and Enterprise Development, 11(4), 449-457. doi:10.1108/14626000410567099

10. Egbu, C. O., Hari, S., \& Renukappa, S. H. (2005). Knowledge management for sustainable competitiveness in small and medium surveying practices. Structural Survey, 23(1), 7-21. doi:10.1108/02630800510586871

11. Gilmore, A., Carson, D., \& Grant, K. (2001). SME marketing in practice. Marketing Intelligence \& Planning, 19(1), 6-11. doi:10.1108/02634500110363583

12. Gracia. A., Magistris, T. D. \& Albisu, L. M. (2011). Supply Chain Relationships and SME Firms' Competitiveness in the Spanish Pig-to-Cured Ham Chain, Journal of International Food \& Agribusiness Marketing, 23, 192-210, doi: 10.1080/08974438.2011.586908

13. Gunasekaran, A., Rai, B. K., \& Griffin, M. (2011). Resilience and competitiveness of small and medium size enterprises: an empirical research. International Journal of Production Research, 49(18), 5489-5509. doi:10.1080/00207543.2011.563831

14. Hussain, J., Millman, C., \& Matlay, H. (2006). SME financing in the UK and in China: a comparative perspective. Journal of Small Business and Enterprise Development, 13(4), 584-599. doi:10.1108/14626000610705769. 
15. Jones, P. (2001). Are educated workers really more productive? Journal of Development Economics, 64(1), 57-79. doi:10.1016/s0304-3878(00)00124-3

16. Karaev, A., Lenny Koh, S. C., \& Szamosi, L. T. (2007). The cluster approach and SME competitiveness: a review. Journal of Manufacturing Technology Management, 18(7), 818-835. doi:10.1108/17410380710817273.

17. Kato, M., Okamuro, H., \& Honjo, Y. (2015). Does founders' human capital matter for innovation? Evidence from Japanese start-ups, Journal of Small Business Management, 53(1), 114-128, doi: 10.1111/jsbm.12094

18. Klonowski, D. (2012). Liquidity gaps in financing the SME sector in an emerging market: evidence from Poland. International Journal of Emerging Markets, 7(3), 335-355. doi:10.1108/17 468801211237072

19. Lamprinopoulou, C., \& Tregear, A. (2011). Inter-firm relations in SME clusters and the link to marketing performance. Journal of Business \& Industrial Marketing, 26(6), 421-429. doi:10.1108/08858621111156412

20. Lipsey, R. E., \& Sjöholm, F. (2004). Foreign direct investment, education and wages in Indonesian manufacturing. Journal of Development Economics, 73(1), 415-422. doi:10.1016/ j.jdeveco.2002.12.004

21. Man, T. W. Y., Lau, T. \& Chan, K. F. (1998). Conceptualisation of SMEs' Competitiveness: A Focus on Entrepreneurial Competencies. Retrieved from www.sbaer.uca.edu/research/icsb/1998/27. pdf

22. Morgan, R. M. \& Hunt, S. D. (1994). Relationship marketing in the era of network competition. Marketing Management, 3(1), 18-28.

23. Neupert, K. E., Baughn, C. C., \& Thanh Lam Dao, T. (2006). SME exporting challenges in transitional and developed economies. Journal of Small Business and Enterprise Development, 13(4), 535-545. doi:10.1108/14626000610705732

24. Passemard, D., \& Kleiner, B. H. (2000). Competitive advantage in global industries. Management Research News, 23(7/8), 111-117. doi:10.1108/01409170010782307

25. Pavlov, A., \& Bourne, M. (2011). Explaining the effects of performance measurement on performance. International Journal of Operations \& Production Management, 31(1), 101-122. doi:10.1108/01443571111098762

26. Porter, M. E. (1985). Competitive advantage: creating and sustaining superior performance. New York.

27. Porter, M. E. (1990). The Competitive Advantage of Nations. New York: Free Press, MacMillan.

28. Randelli, F., \& Lombardi, M. (2013). The Role of Leading Firms in the Evolution of SME Clusters: Evidence from the Leather Products Cluster in Florence. European Planning Studies, 22(6), 1199-1211. doi:10.1080/09654313.2013.773963

29. Richbell, S., Szerb, L., \& Vitai, Z. (2010). HRM in the Hungarian SME sector. Employee Relations, 32(3), 262-280. doi:10.1108/01425451011038799

30. Rostek, K. (2012). The reference model of competitiveness factors for SME medical sector. Economic Modelling, 29(5), 2039-2048. doi:10.1016/j.econmod.2012.03.002 
31. Şener, S., Savrul, M., \& Aydın, O. (2014). Structure of Small and Medium-Sized Enterprises in Turkey and Global Competitiveness Strategies. Procedia - Social and Bebavioral Sciences, 150, 212-221. doi:10.1016/j.sbspro.2014.09.119

32. Tambunan, T. (2008). SME Development in Indonesia: Do Economic Growth and Government Supports Matter? SSRN Electronic Journal. doi:10.2139/ssrn.1218922

33. Tambunan, T. (2009). Export-oriented small and medium industry clusters in Indonesia. Journal of Enterprising Communities: People and Places in the Global Economy, 3(1), 25-58. doi:10.110 $8 / 17506200910943661$

\section{Contact Information}

Dr. Anton Agus Setyawan (Senior Lecturer)

Muzakar Isa, SE, MSc (PhD Candidate)

Dr. Mubammad Farid Wajdi (Senior Lecturer)

Syamsudin, $M B A$ (PhD Candidate)

Sidiq Permono Nugroho, $M B A$ (Lecturer)

Business and Management Research Center

Department of Management Faculty of Economic and Business

Mubammadiyah University of Surakarta

Jl A Yani Tromol Pos 1 Pabelan Kartasura Sukoharjo 57162

Jawa Tengab Indonesia

E-mail:anton.setyawan@ums.ac.id 